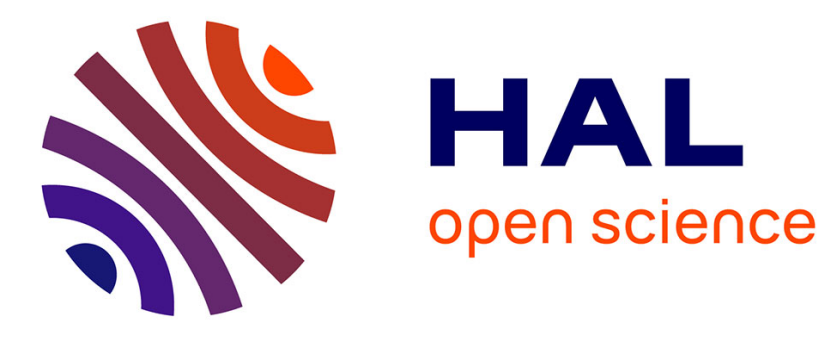

\title{
Temporal pole epilepsy surgery-Sparing the hippocampus
}

\author{
Bastien Herlin, Claude Adam, Marie-Odile Habert, Bertrand Mathon, \\ Stéphane Clemenceau, Vincent Navarro, Sophie Dupont
}

\section{To cite this version:}

Bastien Herlin, Claude Adam, Marie-Odile Habert, Bertrand Mathon, Stéphane Clemenceau, et al.. Temporal pole epilepsy surgery-Sparing the hippocampus. Epilepsia, 2020. hal-03020735

\section{HAL Id: hal-03020735 \\ https: / hal.sorbonne-universite.fr/hal-03020735}

Submitted on 24 Nov 2020

HAL is a multi-disciplinary open access archive for the deposit and dissemination of scientific research documents, whether they are published or not. The documents may come from teaching and research institutions in France or abroad, or from public or private research centers.
L'archive ouverte pluridisciplinaire HAL, est destinée au dépôt et à la diffusion de documents scientifiques de niveau recherche, publiés ou non, émanant des établissements d'enseignement et de recherche français ou étrangers, des laboratoires publics ou privés. 


\section{Temporal pole epilepsy surgery - Sparing the hippocampus}

Bastien Herlin, MD ${ }^{1,2,3}$, Claude Adam, $\mathrm{MD}^{1}$, Marie-Odile Habert, MD, PhD ${ }^{4,5}$, Bertrand Mathon, $\mathrm{MD}^{3,6,7}$, Stéphane Clemenceau, $\mathrm{MD}^{6}$, Vincent Navarro, $\mathrm{MD}, \mathrm{PhD}^{1,3,7 *}$, Sophie Dupont, $\mathrm{MD}, \mathrm{PhD}^{1,2,3,7 *}$

${ }^{1}$ AP-HP Pitié-Salpêtrière Hospital, Epileptology Unit, Paris, France

${ }^{2}$ AP-HP Pitié-Salpêtrière Hospital, Rehabilitation Unit, Paris, France

${ }^{3}$ Sorbonne Université, Paris, France

${ }^{4}$ AP-HP Pitié-Salpêtrière Hospital, Department of Nuclear Medicine, F-75013, Paris, France

${ }^{5}$ Sorbonne Université, CNRS, INSERM, Laboratoire d'Imagerie Biomédicale, LIB, F-75006,

Paris, France

${ }^{6}$ AP-HP Pitié-Salpêtrière Hospital, Neurosurgery Department, Paris, France

${ }^{7}$ Paris Brain Institute, ICM, INSERM, CNRS, Paris, France

* Equally contributed

\section{Corresponding author:}

Dr Bastien Herlin

Epileptology Unit, Pitié-Salpêtrière Hospital, 47, boulevard de l'Hôpital, 75013 Paris, France

Phone/FAX: (33) 1421603 01/142160303

Mail: bastien.herlin@aphp.fr 


\section{Acknowledgement}

This work received support from the "Investissements d'avenir" program ANR-10-IAIHU-06, and from the Fondation Assistance Publique Hôpitaux de Paris (EPIRES - Marie Laure PLV Merchandising).

All author reports no disclosures or conflict of interest.

\section{Ethical statement}

We confirm that we have read the Journal's position on issues involved in ethical publication and affirm that this report is consistent with those guidelines. 


\section{Abstract:}

Temporal pole epilepsy (TPE) is a poorly known and difficult to individualize subtype of temporal lobe epilepsy. Consequently, in drug-resistant TPE, there is still a debate on the need for a large surgical removal of the temporal pole and mesial temporal structures or a limited resection of the temporal pole. We reviewed all patients who underwent presurgical evaluation for drug-resistant epilepsy over a 17-year period, and report here 19 patients with proven drug-resistant temporal pole epilepsy who underwent a selective temporal pole resection with respect of mesial structures. Most (15) TPE patients exhibited seizures resembling mesio-temporal seizures, whereas the others exhibited nocturnal hyperkinetic seizures or an association of both seizure types. MRI revealed a temporal pole lesion in $58 \%$ of patients. Long-term postoperative outcome after a conservative surgery was excellent: $63 \%$ of patients were seizure-free (ILAE 1) at one-year post-surgery and $78 \%$ at 5 years. These results show that TPE has no specific electroclinical features but is a distinct type of temporal lobe epilepsy allowing a conservative surgery. Respecting the mesio-temporal structures is a valid surgical approach for drug-resistant temporal pole epilepsy. 


\section{Introduction:}

The involvement of the temporal pole has already been substantiated in mesial temporal lobe epilepsy (MTLE), as assessed by intracranial recording of MTLE patients showing early propagation of the epileptic discharge arising from the hippocampus to the temporal pole ${ }^{1}$, MRI temporal pole blurring frequently associated with hippocampal sclerosis $(\mathrm{HS})^{2}$, and temporal pole hypometabolism frequently found in FDG-PET of MTLE patients with $\mathrm{HS}^{3}$. Nevertheless, little is known about seizures that arise directly from the temporal pole. Many questions remain: are temporal pole seizures clinically distinct from MTL seizures? Are there any specific symptoms related to an epileptic discharge located in the temporal pole, or are symptoms due to secondary involvement of adjacent structures? If a surgery is considered for drug-resistant temporal pole epilepsy (TPE), what kind of resection should be proposed: anterior temporal resection involving the temporal pole, amygdala and hippocampus, or focal resection restricted to the temporal pole? ${ }^{7}$

To address these questions, we aimed to better characterize the electroclinical profiles of TPE patients and to demonstrate that TPE is a distinct subtype of TLE allowing a conservative surgical approach sparing the hippocampus. We therefore examined long-term postsurgical outcome of patients with drug-resistant TPE who underwent selective temporal pole resection.

\section{Methods:}

We selected all patients with drug-resistant TPE who underwent selective temporal pole resection between 2000 and 2017 at the Pitié-Salpêtrière Hospital (Paris, France) Epileptology Unit. 
All patients underwent a standardized presurgical evaluation including a long-term videoEEG monitoring, a dedicated structural MRI and a neuropsychological assessment. All patients underwent the same imaging protocol on a 1.5T or 3T MRI depending on the year, including 3mm-thick coronal fluid-attenuated inversion recovery (FLAIR) and T2-weighted sequences, $3 \mathrm{~mm}$-thick axial T2 and T2* sequences, and volumetric pulse sequences (3DT1) reformatted in axial, sagittal and coronal planes.

If necessary, further examinations were performed to delineate the epileptogenic focus including FDG-PET, interictal-ictal SPECT, and intracranial EEG recording (sEEG).

All surgeries were done at the Pitié-Salpêtrière Hospital Neurosurgery Department. For the surgery, the patient is positioned supine, with the shoulder elevated, and the head turned about $75^{\circ}$ contralaterally while being extended to make the zygomatic arch the highest point of the operative field. Scalp incision is a small curvilinear shape that starts at the superior border of the zygomatic arch just in front of the tragus, extends to the superior temporal line and anteriorly to the hairline. The temporalis muscle is incised via a curvilinear incision and retracted anteriorly. Two burr holes are placed on each side of the sphenoid wing. A small temporal craniotomy is fashioned to expose the superior and middle temporal gyri, and the sylvian fissure. The sphenoid wing is flattened with a rongeur to allow adequate exposure to the anterior part of the temporal pole. The dura is opened in a semicircular fashion and reflected over the temporalis muscle. Using an ultrasonic aspirator, a cortectomy is made about $3 \mathrm{~cm}$ from the temporal tip in the dominant hemisphere and $4 \mathrm{~cm}$ from the temporal tip in a non-dominant hemisphere. Identifying the temporal horn of the ventricle marked the medial extent of the resection. Intraoperative MRI or electrophysiology were not used. 
Epilepsy surgery outcome was assessed using ILAE classification at 1, 3 and 5 years after surgery.

All the patients gave their informed consent to the use and publication of data related to their epilepsy at the time of video-EEG.

\section{Results:}

\section{Clinical characteristics}

Nineteen patients (15 males, 4 females) were identified. Demographic and clinical data are summarized in table 1. In most cases, TPE started during childhood (median age at first seizure: 13 years \pm 8 ) and median age at surgery was 25 years \pm 10 . Preoperative average seizure frequency was 37 per month (min 1/month, max 150/month). All patients had antiepileptic drug polytherapy, ranging from 2 to 4 antiepileptic drugs (mean: 2.5 drugs). Patients with TPE experienced different seizure types. 15 patients had seizures resembling mesio-temporal seizure, starting with rising epigastric sensation, déjà-vu, or feeling of fear, followed by loss of awareness and gestural or swallowing automatisms. Two patients had nocturnal hyperkinetic seizures and two patients had both diurnal MTLE-type seizures and nocturnal hyperkinetic seizures. 8 of 19 patients also had focal seizures evolving to bilateral tonic-clonic seizures.

Neuropsychological assessment was normal in 7 patients. 8 patients had episodic memory impairment compatible with the lateralization of their epilepsy (visual memory deficiency for patient with right-sided TPE, verbal memory deficiency for patient with left-sided TPE), and 4 patients had both visual and verbal episodic memory impairment. 8 patients also exhibited signs of frontal dysfunction (attention impairment, dysexecutive syndrome). 
Imaging and electrophysiological characteristics

Brain MRI was performed at 1.5T in 2 patients and $3 \mathrm{~T}$ in 17 patients. It showed a temporal pole lesion in 11 of 19 patients (Table 1).

Ten patients, including the 8 patients with normal MRI, had an FDG-PET. It showed a unilateral temporopolar hypometabolism in all patients, associated with an ipsilateral mesiotemporal hypometabolism in 3 patients and an orbitofrontal hypometabolism in 4 patients.

Ten patients had an interictal-ictal SPECT. It showed a predominant temporopolar hyperperfusion in 3 patients, and a more diffuse hyperperfusion pattern (ipsilateral temporopolar, mesiotemporal and orbitofrontal hyperperfusion) in 7 patients.

Examples of imaging finding are shown in figure 1.

Seven of 8 patients with a normal MRI had intracranial EEG recording, assessing that the seizure onset zone was located in the temporal pole. Clinical and electrophysiological data are summarized in Table 2. For all patients, the epileptic discharge spread to the ipsilateral hippocampus and amygdala during the first seconds after seizure onset. For two patients, it secondarily spread to the ipsilateral orbitofrontal cortex. Symptoms associated with an epileptic discharge strictly located to the temporal pole were indistinguishable from MTLE symptoms. Electrical stimulations on temporal pole electrodes ( $n=5$ patients) elicited the same MTLE symptoms in three patients. Spreading to the ipsilateral hippocampus was associated with loss of awareness, while spreading to the orbitofrontal cortex was associated with motor manifestations.

\section{Surgery outcome}


Histopathological findings were consistent with imaging findings for the $11 \mathrm{MRI}$-positive patients. For the $8 \mathrm{MRI}$-negative patients, histopathological analyses showed slight cytoarchitectural alterations (neuronal heterotopia or non-specific gliosis) in 6 patients and no anomalies in 2.

Surgery outcome was assessed using ILAE classification at 1, 3 and 5 years after surgery (Figure 2).

At 1 year after surgery, 12 patients (63\%) were seizure-free (ILAE 1) and 2 patients (11\%) had only auras with no other seizure (ILAE 2). The 5 remaining patients had at least 4 seizures per year with a $50 \%$ reduction of their baseline seizure frequency (ILAE 4).

Several patients had further improvement between the first and the third year after surgery. Therefore, at 3 years after surgery, 15 patients (79\%) were classified ILAE 1, and only 2 were still ILAE 4.

At 5 years after surgery, one patient was lost during follow-up (he was ILAE 1 at 1 and 3 years). For the 18 remaining patients, 14 patients (78\%) were classified as ILAE 1 . Their antiepileptic medications were gradually decreased: at 5 years, 9 patients were on antiepileptic drug monotherapy and treatment was discontinued in 5 patients.

All patients had a neuropsychological assessment 1 year after surgery. It showed identical results in comparison with the pre-operative neuropsychological assessment in 13 patients, slight worsening of episodic memory in 4 patients (verbal episodic memory worsening after left TPE surgery in 3 patients, and visual episodic memory worsening after right TPE surgery in one patient), and improvement of executive functions in 2 patients.

\section{Discussion:}


Our study pointed two major findings: TPE has no specific electroclinical feature, and a conservative resection sparing the hippocampus is a viable surgical approach for drugresistant TPE.

\section{Electroclinical features}

Some previous studies reported that most TPE patients exhibited nocturnal hyperkinetic seizures $^{5,7,9,10}$. In our study, nocturnal hyperkinetic seizures was found in 4 of 19 patients, i.e. $21 \%$, which is higher than usually found in TLE (6\% in Staack's cohort $\left.{ }^{7}\right)$. Most of our patients had focal seizures with impaired awareness mimicking MTLE seizures. The only distinctive features of TPE compared with MTLE were the higher seizures frequency (37/month in TPE, vs $6 /$ month in our MTLE cohort $\left.{ }^{6}\right)$, and the absence of febrile seizure during childhood $(0 / 19$ TPE patients). TPE may thus mimic either MTLE or frontal lobe epilepsy, certainly depending of the preferential spreading of the epileptic discharge. A fast spreading to the ipsilateral mesio-temporal structures was found in all patients who underwent sEEG, which was associated with MTLE symptoms, and the nocturnal hyperkinetic seizures might be related to the spread to the frontal lobe.

TPE is a rare subtype of temporal lobe epilepsy, accounting for only a small number of TLE patients: over the same period, in our centre, 308 patients had a surgery for drug-resistant $\mathrm{MTLE}^{5}$, including 214 associated with hippocampal sclerosis and 94 associated with other etiology (focal cortical dysplasia, DNET...). However, TPE is hard to identify and individualize. In our cohort, MRI-negative TPE patients underwent sEEG with implantation scheme sampling the mesial temporal structure (hippocampus and amygdala), enabling us to assess that the seizures indeed started from the temporal pole and secondarily spread to the mesial temporal structure. On the other side, some MRI-negative patients might have been 
falsely identified as MTLE instead of TPE if we missed a temporal pole onset during sEEG due to an insufficient sampling of the temporal pole.

\section{Surgical approach and postoperative outcome}

Our study is the first one reporting postoperative outcome of patients with drug-resistant TPE after a conservative surgery sparing the mesial temporal structures. In the only other cohort of patients with temporal pole epilepsy, Wang et al $^{12}$ reported 8 patients who underwent a surgery, 6 of which had anterior temporal lobectomy including amygdalohippocampectomy, and only 2 had a conservative surgery.

The excellent surgical outcome in our cohort (79\% patients ILAE I at 3 year after surgery and $78 \%$ at 5 years) is similar to the best results of MTLE surgery. In a 2015 Cochrane metaanalysis $^{13}, 69 \%$ of patients were Engel class I (which approximately correspond to ILAE 1 and 2 ) at 1 year after temporal lobe surgery, and $74 \%$ in case of hippocampal sclerosis. In our previously published cohort of MTLE patients ${ }^{5}$, seizure outcome after surgery was classified Engel I in $83.7 \%$ patients at 8.7 years.

For the two patients classified ILAE 4 at 5 years, a missed mesiotemporal onset of the seizure might be considered, but they had both benefited from presurgical sEEG, sampling temporal pole, hippocampus and amygdala, that did assess an onset in the temporal pole. Another hypothesis might be a second epileptogenic focus not recorded during sEEG. The patients were proposed a second presurgical evaluation, but they declined it.

Temporal lobe resections sparing the hippocampus have a cognitive benefit compared with resections including the hippocampus, such as a benefit in verbal learning performance in resections within the dominant hemisphere ${ }^{10}$, but they can still be associated with a decline in memory performances. Wagner et al ${ }^{11}$ demonstrated that any resection within the 
temporal lobe might lead to a secondary hippocampal atrophy, and thus a memory decline. This could explain the slight worsening of episodic memory seen in 4 of our patients at one year post-surgery. Nevertheless, as the majority of our patients (13/19) did not show any neuropsychological worsening after surgery, we recommend to spare the hippocampus in temporal pole epilepsy.

Limitation of the study

The main limitation of our study is the lack of a comparative group. In our centre, we favoured the most conservative surgical approach, therefore no TPE patient underwent anterior temporal resection including the mesial structures.

\section{Conclusion}

TPE is a specific epileptic syndrome with electroclinical features resembling MTLE, except for a higher seizure frequency and the absence of febrile seizure during childhood. TPE must be differentiated from MTLE, and may require intracranial EEG in the absence of MRI lesion. TPE is accessible to a conservative resective surgery, sparing the mesial temporal structures, with a good surgical outcome both in terms of seizure freedom and memory outcome. 


\section{References:}

1. Abel TJ, Woodroffe R, Moritani T, Kirby P, Howard MA, Kawasaki H, et al. The role of the temporal pole in temporal lobe seizure networks: an intracranial electrode investigation. Neurosurgery. 2016;63(Suppl 1).

2. Temporal pole abnormalities in temporal lobe epilepsy with hippocampal sclerosis: Clinical significance and seizure outcome after surgery. Di Gennaro G, D'Aniello A, De Risi M, Grillea G, Quarato PP, Mascia A, Grammaldo LG, Casciato S, Morace R, Esposito V, Picardi A. Seizure. 2015;32:84-91.

3. Fountas KN, Tsougos I, Gotsis ED, Giannakodimos S, Smith JR, Kapsalaki EZ. Temporal pole proton preoperative magnetic resonance spectroscopy in patients undergoing surgery for mesial temporal sclerosis. Neurosurg Focus. 2012;32:E3.

4. Gil-Nagel A, Risinger MW. Ictal semiology in hippocampal versus extrahippocampal temporal lobe epilepsy. Brain. 1997;120:183-92.

5. Mai R, Sartori I, Francione S, Tassi L, Castana L, Cardinale F, et al. Sleep-related hyperkinetic seizures: always a frontal onset? Neurol Sci. 2005;26:s220-4.

6. Mathon B, Bielle F, Samson S, Plaisant O, Dupont S, Bertrand A, Miles R, NguyenMichel VH, Lambrecq V, Calderon-Garcidueñas AL, Duyckaerts C, Carpentier A, Baulac M, Cornu P, Adam C, Clemenceau S, Navarro V. Predictive factors of long-term outcomes of surgery for mesial temporal lobe epilepsy associated with hippocampal sclerosis. Epilepsia. 2017;58:1473-1485. 
7. Staack AM, Bilic S, Wendling AS, Scholly J, Kraus U, Strobl K, et al. Hyperkinetic seizures in patients with temporal lobe epilepsy: clinical features and outcome after temporal lobe resection. Epilepsia. 2011;52:1439-46.

8. Tonini C, Beghi E, Berg AT, Bogliun G, Giordano L, Newton RW, et al. Predictors of epilepsy surgery outcome: a meta-analysis. Epilepsy Res. 2004;62:75-87.

9. Vaugier L, Aubert S, McGonigal A, Trébuchon A, Guye M, Gavaret M, et al. Neural networks underlying hyperkinetic seizures of "temporal lobe" origin. Epilepsy Res. $2009 ; 86: 200-8$

10. Wagner K, Uherek M, Horstmann S, Kadish NE, Wisniewski I, Mayer H, et al. Memory outcome after hippocampus sparing resections in the temporal lobe. J Neurol Neurosurg Psychiatry. 2013;84:630-6.

11. Wagner K, Gau K, Metternich B, Geiger MJ, Wendling AS, Kadish NE, et al. Effects of hippocampus-sparing resections in the temporal lobe: Hippocampal atrophy is associated with a decline in memory performance. Epilepsia. 2020;61:725-734

12. Wang L, Mathews GC, Whetsell WO, Abou-Khalil B. Hypermotor seizures in patients with temporal pole lesions. Epilepsy Res. 2008;82:93-8.

13. West S, Nolan SJ, Cotton J, Gandhi S, Weston J, Sudan A, et al. Surgery for epilepsy. Cochrane Database Syst Rev. 2015:CD010541. 
Tables and figures:

Table 1. Summary of patient demographic, clinical and paraclinical data

\begin{tabular}{|c|c|}
\hline Gender & $M: 15 / F: 4$ \\
\hline Epilepsy risk factor & $\begin{array}{l}\text { Febrile seizure during childhood: 0/19 } \\
\text { Prematurity: } 2 / 19 \text { (10.5 \%) } \\
\text { Familial history of epilepsy: 0/19 } \\
\text { Cranial trauma: 0/19 }\end{array}$ \\
\hline $\begin{array}{l}\text { Age at } 1^{\text {st }} \text { seizure: median (minimum- } \\
\text { maximum), years }\end{array}$ & $13(3-33)$ \\
\hline $\begin{array}{c}\text { Age at surgery: median (minimum-maximum), } \\
\text { years }\end{array}$ & $25(17-50)$ \\
\hline $\begin{array}{l}\text { Seizure frequency: median (minimum- } \\
\text { maximum) }\end{array}$ & $37 /$ month (5/month - $10 /$ day) \\
\hline Epilepsy lateralisation & Left: 11 (58 \%) / Right: 8 (42 \%) \\
\hline MRI findings & $\begin{array}{l}\text { Normal MRI: } 8 \text { /Temporal pole lesions: } 11 \\
\text { Cystic lesion: } 3 \\
\text { Cortical dysplasia: } 3 \\
\text { Tumoral lesion: } 4 \\
\text { Cerebral cavernous malformation: } 1\end{array}$ \\
\hline Interictal scalp EEG findings & $\begin{array}{l}\text { Homolateral temporal spikes: 19/19 (100\%) } \\
\text { Contralateral temporal spikes: 4/19 (21\%) } \\
\text { Homolateral frontal spikes: } 3 / 19(16 \%)\end{array}$ \\
\hline Histopathology & $\begin{array}{c}\text { Focal cortical dysplasia: } 3 \\
\text { DNET: } 3 \\
\text { Ganglioglioma: } 2 \\
\text { Dermoid cyst: } 1 \\
\text { Ependymal cyst: } 1 \\
\text { Arachnoïd cyst: } 1 \\
\text { Neuronal heterotopia: } 2 \\
\text { Gliosis: } 4 \\
\text { No anomaly: } 2\end{array}$ \\
\hline
\end{tabular}


Table 2. Clinical and electrophysiological data during seizures and electrical stimulations for the 7 TPE patients who underwent sEEG.

\begin{tabular}{|c|c|c|c|c|}
\hline Patients & Seizure onset & $\begin{array}{l}\text { Early spreading (1 to } 10 \\
\text { seconds after seizure } \\
\text { onset) }\end{array}$ & $\begin{array}{l}\text { Late spreading } \\
\text { (more than } 10 \\
\text { seconds after } \\
\text { seizure onset) }\end{array}$ & Electrical stimulation \\
\hline \multirow{2}{*}{$\begin{array}{l}\text { Patient } 1 \\
\text { Histology: } \\
\text { neuronal } \\
\text { heterotopia }\end{array}$} & $\begin{array}{l}\text { Anterior } \\
\text { temporopolar fast } \\
\text { discharge }\end{array}$ & Ipsilateral hippocampus & $\begin{array}{l}\text { No late } \\
\text { spreading }\end{array}$ & \multirow{2}{*}{$\begin{array}{l}\text { Temporal pole } \\
\text { stimulation: feeling of } \\
\text { fear or joy } \\
\text { Hippocampus } \\
\text { stimulation: feeling of } \\
\text { fear or joy }\end{array}$} \\
\hline & No symptom & $\begin{array}{l}\text { Feeling of anxiety and } \\
\text { fear, followed by loss of } \\
\text { awareness }\end{array}$ & NA & \\
\hline \multirow{2}{*}{$\begin{array}{l}\text { Patient } 2 \\
\text { Histology: } \\
\text { gliosis }\end{array}$} & $\begin{array}{l}\text { Mesial } \\
\text { temporopolar fast } \\
\text { discharge }\end{array}$ & $\begin{array}{l}\text { Ipsilateral amygdala, } \\
\text { hippocampus, and mesial } \\
\text { temporo-basal cortex }\end{array}$ & $\begin{array}{l}\text { Ipsilateral } \\
\text { orbitofrontal } \\
\text { cortex }\end{array}$ & \multirow{2}{*}{$\begin{array}{l}\text { Temporal pole } \\
\text { stimulation: not } \\
\text { practiced (technical } \\
\text { issue) } \\
\text { Hippocampus } \\
\text { stimulation: triggers an } \\
\text { amygdalo-hippocampal } \\
\text { rhythmic discharge, } \\
\text { associated with } \\
\text { paleness and aphasia }\end{array}$} \\
\hline & $\begin{array}{l}\text { Gustatory } \\
\text { hallucination, } \\
\text { memory recall }\end{array}$ & Loss of awareness & $\begin{array}{l}\text { Contralateral } \\
\text { arm dystonia, } \\
\text { contralateral } \\
\text { tonic head } \\
\text { deviation }\end{array}$ & \\
\hline \multirow[t]{2}{*}{$\begin{array}{l}\text { Patient } 3 \\
\text { Histology: } \\
\text { neuronal } \\
\text { heterotopia }\end{array}$} & $\begin{array}{l}\text { Basal } \\
\text { temporopolar and } \\
\text { anterior } \\
\text { temporopolar fast } \\
\text { discharge }\end{array}$ & Ipsilateral hippocampus & $\begin{array}{l}\text { Ipsilateral } \\
\text { fronto-insular } \\
\text { areas }\end{array}$ & \multirow{2}{*}{$\begin{array}{l}\text { Temporal pole } \\
\text { stimulation: triggers a } \\
\text { focal seizure with the } \\
\text { same electrical pattern } \\
\text { and the same } \\
\text { symptoms than } \\
\text { spontaneous seizure } \\
\text { Hippocampus } \\
\text { stimulation: triggers an } \\
\text { asymptomatic } \\
\text { temporopolar fast } \\
\text { discharge }\end{array}$} \\
\hline & $\begin{array}{l}\text { Tachycardia, } \\
\text { feeling of } \\
\text { " adrenaline } \\
\text { rush » }\end{array}$ & Loss of awareness & $\begin{array}{l}\text { Shout, bilateral } \\
\text { upper limbs } \\
\text { hyperkinetic } \\
\text { movements }\end{array}$ & \\
\hline $\begin{array}{l}\text { Histology: } \\
\text { no anomaly }\end{array}$ & $\begin{array}{l}\text { Anterior } \\
\text { temporopolar } \\
\text { onset with fast } \\
\text { involvement } \\
\text { (200ms) of } \\
\text { ipsilateral } \\
\text { temporo-basal } \\
\text { cortex and }\end{array}$ & $\begin{array}{l}\text { Ipsilateral hippocampus, } \\
\text { then contralateral } \\
\text { hippocampus }\end{array}$ & $\begin{array}{l}\text { No late } \\
\text { spreading }\end{array}$ & Not done \\
\hline
\end{tabular}




\begin{tabular}{|c|c|c|c|c|}
\hline & amygdala & & & \\
\hline & $\begin{array}{l}\text { Loss of awareness, } \\
\text { hand and oral } \\
\text { automatisms }\end{array}$ & $\begin{array}{l}\text { Loss of awareness, hand } \\
\text { automatisms, polypnea, } \\
\text { tachycardia }\end{array}$ & NA & \\
\hline \multirow[t]{2}{*}{ Patient 5} & $\begin{array}{l}\text { Temporopolar fast } \\
\text { discharge, with } \\
\text { fast spreading } \\
\text { ( } 200 \mathrm{~ms} \text { ) to the } \\
\text { ipsilateral external } \\
\text { temporal cortex }\end{array}$ & $\begin{array}{l}\text { Ipsilateral amygdala and } \\
\text { hippocampus }\end{array}$ & $\begin{array}{l}\text { No late } \\
\text { spreading }\end{array}$ & \multirow{2}{*}{$\begin{array}{l}\text { Temporal pole } \\
\text { stimulation: triggers a } \\
\text { fast discharge } \\
\text { associated with a } \\
\text { feeling of seizure onset } \\
\text { (nausea, feeling of } \\
\text { strangeness) } \\
\text { Hippocampus } \\
\text { stimulation: cough, } \\
\text { nausea }\end{array}$} \\
\hline & $\begin{array}{l}\text { Head and eye } \\
\text { contralateral tonic } \\
\text { deviation, nausea }\end{array}$ & $\begin{array}{l}\text { Loss of awareness, hand } \\
\text { and oral automatisms }\end{array}$ & NA & \\
\hline \multirow{2}{*}{$\begin{array}{l}\text { Patient } 6 \\
\text { Histology: } \\
\text { gliosis }\end{array}$} & $\begin{array}{l}\text { Basal } \\
\text { temporopolar fast } \\
\text { discharge }\end{array}$ & $\begin{array}{l}\text { Ipsilateral inferior } \\
\text { temporal cortex and } \\
\text { hippocampus }\end{array}$ & $\begin{array}{l}\text { No late } \\
\text { spreading }\end{array}$ & \multirow{2}{*}{$\begin{array}{l}\text { Temporal pole } \\
\text { stimulation: triggers an } \\
\text { asymptomatic fast } \\
\text { discharge } \\
\text { Hippocampus } \\
\text { stimulation: nausea } \\
\text { (not recognized by the } \\
\text { patient as a symptom } \\
\text { of its seizure) }\end{array}$} \\
\hline & $\begin{array}{l}\text { Loss of awareness, } \\
\text { motor and oral } \\
\text { automatisms }\end{array}$ & $\begin{array}{l}\text { Ipsilateral hand } \\
\text { automatisms, } \\
\text { contralateral upper limb } \\
\text { dystonia }\end{array}$ & NA & \\
\hline \multirow[t]{2}{*}{$\begin{array}{l}\text { Patient } 7 \\
\text { Histology: } \\
\text { gliosis }\end{array}$} & $\begin{array}{l}\text { Temporopolar fast } \\
\text { discharge }\end{array}$ & $\begin{array}{l}\text { Ipsilateral inferior } \\
\text { temporal cortex }\end{array}$ & $\begin{array}{l}\text { Ipsilateral } \\
\text { hippocampus }\end{array}$ & \multirow{2}{*}{$\begin{array}{l}\text { Temporal pole } \\
\text { stimulation: palpitation } \\
\text { and rising epigastric } \\
\text { sensation, followed by } \\
\text { an asymptomatic } \\
\text { temporal pole post- } \\
\text { discharge } \\
\text { Anterior hippocampus } \\
\text { stimulation: fear and } \\
\text { rising epigastric } \\
\text { sensation }\end{array}$} \\
\hline & $\begin{array}{l}\text { Rising epigastric } \\
\text { sensation }\end{array}$ & $\begin{array}{l}\text { Loss of awareness, } \\
\text { gestural automatisms }\end{array}$ & $\begin{array}{l}\text { Loss of } \\
\text { awareness, } \\
\text { gestural } \\
\text { automatisms }\end{array}$ & \\
\hline
\end{tabular}


Figure 1. Example of preoperative assessment in an MRI-negative patient. A: FDG-PET

showing left temporopolar (white arrow) and orbitofrontal hypometabolism. B: subtraction ictal SPECT coregistered with MRI (SISCOM) showing left anterior temporal hyperperfusion. C: Normal preoperative axial and sagittal T1 MRI. D: Postoperative axial and sagittal MRI showing left temporal pole resection (red arrow) with preservation of left mesial temporal structures (blue arrow)
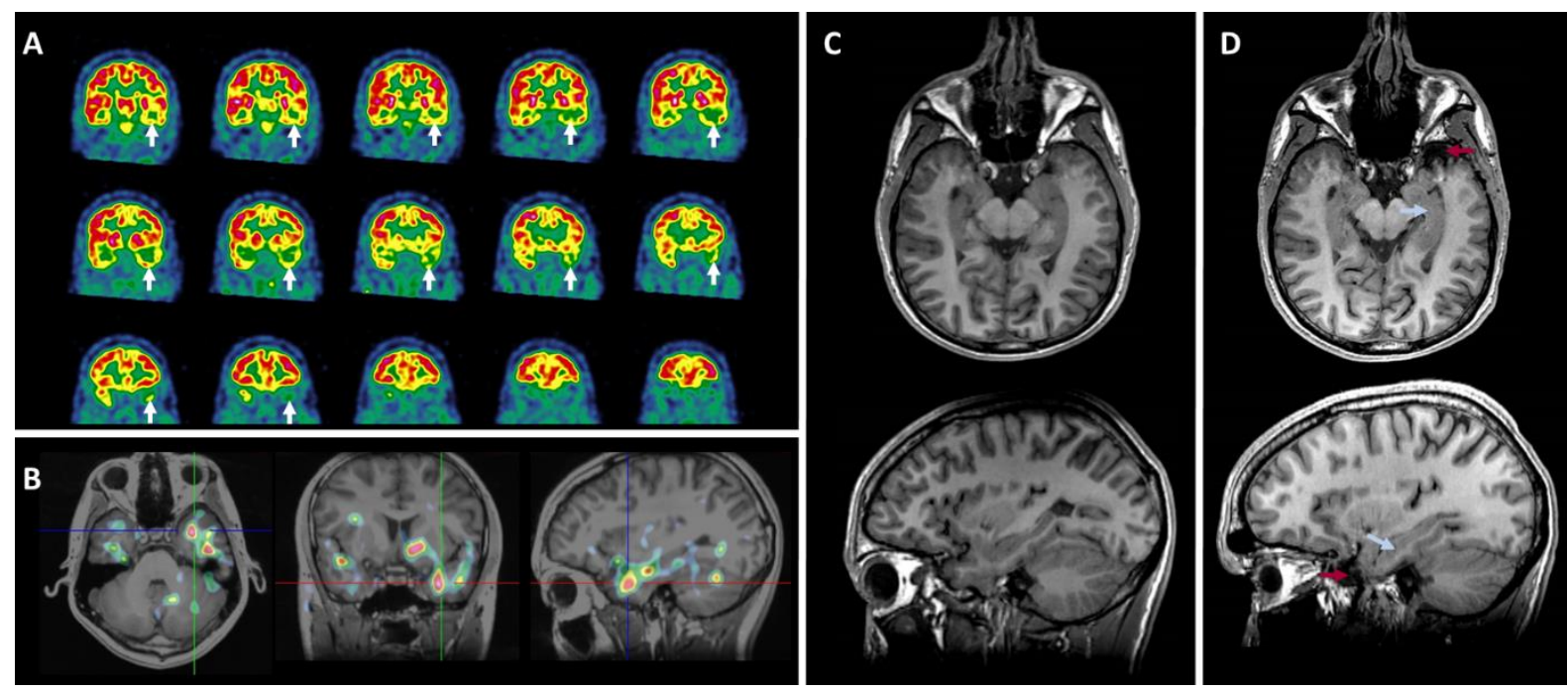
Figure 2. Surgery outcome at 1, 3 and 5 years, using ILAE classification

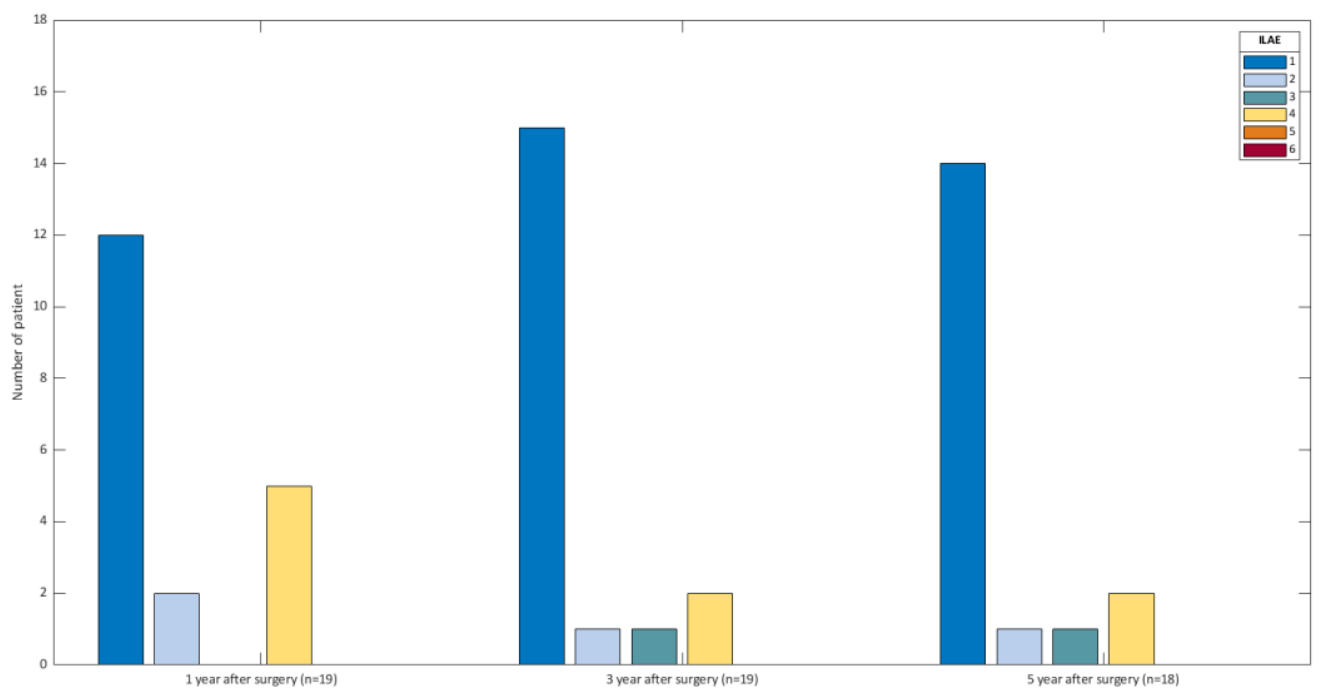

